\title{
Effect of hydraulic loading rate and vegetation on phytoremediation with artificial wetlands associated to natural swimming pools
}

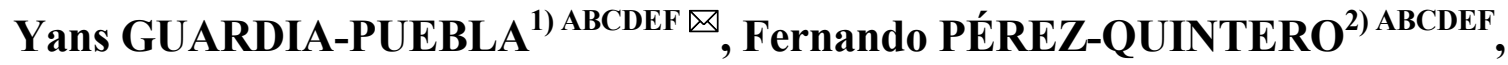 \\ Suyén RODRÍGUEZ-PÉREZ ${ }^{3)}$ ADEF , Víctor SÁNCHEZ-GIRÓN ${ }^{4)}$ CDEF, \\ Edilberto LLANES-CEDEÑO ${ }^{\text {5) DEF, Juan ROCHA-HOYOS }}{ }^{\left({ }^{\text {DEF }}\right.}$, \\ Diana PERALTA-ZURITA ${ }^{\text {7) DEF }}$
}

\footnotetext{
1) orcid.org/0000-0002-1347-0963; University of Granma, Study Center for Applied Chemistry, Granma, Carr. Manzanillo, km 17, Peralejo, Bayamo, 85100 Bayamo, Cuba; e-mail: yguardiapuebla@gmail.com

${ }^{2)}$ University of Oriente, Department of Hydraulic Engineering, Santiago de Cuba, Cuba; e-mail: fernando@uo.edu.cu

3) Center for Molecular Immunology, Santiago de Cuba, Cuba; e-mail: suyen@cim.sld.cu

4) orcid.org/0000-0002-1774-7667; Polytechnic University of Madrid, Higher Technical School of Agronomic, Food and Biosystems Engineering, Spain; e-mail: victor.sanchezgiron@upm.es

${ }^{5)}$ orcid.org/0000-0001-6739-7661; International SEK University, Faculty of Architecture and Engineering, Quito, Ecuador; e-mail: antonio.llanes@uisek.edu.ec

6) orcid.org/0000-0003-0660-7199; International SEK University, Faculty of Architecture and Engineering, Quito, Ecuador; e-mail: carlos.rocha@uisek.edu.ec

7) orcid.org/0000-0002-9523-0743; International SEK University, Faculty of Architecture and Engineering, Quito, Ecuador; e-mail: diana.peralta@uisek.edu.ec
}

For citation: Guardia-Puebla Y., Pérez-Quintero F., Rodríguez-Pérez S., Sánchez-Girón V., Llanes-Cedeño E., Rocha-Hoyos J., PeraltaZurita D. 2019. Effect of hydraulic loading rate and vegetation on phytoremediation with artificial wetlands associated to natural swimming pools. Journal of Water and Land Development. No. 40 (I-III) p. 39-51. DOI: 10.2478/jwld-2019-0004.

\begin{abstract}
The treatment of pool water, whether for recreational or sporting purposes, by phytoremediation is widely applied. This work evaluates two artificial vertical flow wetlands, one on a real scale and the other on a laboratory scale, which have been planted with Typha domingensis, for the treatment of pool water in the climatic conditions of the city of Santiago de Cuba. When the hydraulic load applied to the real scale wetland was less than $0.25 \mathrm{~m}^{3} \cdot \mathrm{m}^{-2} \cdot \mathrm{d}^{-1}$, the levels of organic and microbiological contamination in the pool were below the maximum limits allowed by Cuban standards. At a laboratory scale, the presence of vegetation favoured the elimination of nitrogen compounds (nitrates and ammonium) and organic materials (BOD and COD). This behaviour is explained by the presence of processes of assimilation of organic compounds, or by the action of microorganisms associated with the rhizome of plants, which establish a symbiotic mechanism favourable to phytodepuration. The minimum concentration of ammonium obtained in outflow from the laboratory-scale reactor without vegetation reached a value of $2.15 \mathrm{mg} \cdot \mathrm{m}^{-3}$, which is within the limits allowed by the sanitary regulations.
\end{abstract}

Key words: artificial wetlands, natural swimming pools, phytoremediation, sub-surface flow, Typha domingensis

\section{INTRODUCTION}

Swimming is a highly recommended sport because it has potentially beneficial effects on human health and, in general, on personal well-being. A large sector of the population uses swimming pools for various activities within the sports, recreational or medical environment, even when in these environments people are prone to contracting various types of diseases [POND 2005]. Different types of pathogenic and opportunistic microorganisms that 
are present in the swimming pools can penetrate the body of bathers, either by direct ingestion of water or by other indirect means, causing skin diseases, gastrointestinal illnesses and/or respiratory disorders [WHO 2006]. In addition with the pollution inherent to the sources from which the swimming pool waters come, the main sources of contamination in the swimming pools come from the bathers themselves: i.e. body excretions, lotions and cosmetics, among others [TEO et al. 2015].

Several investigations have been carried out on the chemical contamination of swimming pools, which have focused mainly on means to save the cost of disinfectant products [RICHARDSON et al. 2010; YANG et al. 2016; ZWIENER et al. 2007]. The fundamental priority of the disinfection process in the swimming pools is to maintain the microbiological quality of the water to inhibit the spread of infections and diseases. In order to meet this objective, high concentrations of sodium hypochlorite are commonly used in swimming pools to ensure a water free of microorganisms [RICHARDSON 2010]. Likewise, with the increasing concentrations of chemical compounds in swimming pool waters, much attention has actually been paid to their effect on bathers. Most of the countries, however, have not yet specified the maximum concentration limits of chemical compounds for the disinfection of swimming pool waters, but some countries, such as Germany and France report maximum levels of trihalomethanes (THMs) of 20 and $100 \mu \mathrm{g} \cdot \mathrm{dm}^{-3}$, respectively [FLORENTIN et al. 2011]. Therefore, it is necessary to reduce the levels of chemical contaminants through alternative and emerging methods that improve the quality of swimming pool waters [CHOWDHURY et al. 2014].

Natural swimming pools (NSP) are sources of water which are separated from surface-water and ground-water by artificial constructions. The fundamental characteristic of these pools is that they do not require any chemical disinfection, taking the advantage of their capacity of recovery and constant flow of water. The treatment of the water is carried out through mechanical techniques, biological filters and plants growing in the system. Currently, the demand for natural swimming pools has increased significantly in the world. This increase is due to several factors, i.e.: i) the elimination of chlorinated compounds and other chemical compounds for the disinfection of water; ii) the reduction of toxic compounds formed by the reaction of disinfectants and natural organic matter, process called disinfection by products (DBPs); iii) the aesthetic appeal of natural pools due to the attractive designs used; and iv) the low costs of construction, operation and maintenance compared to other available methods [CASANOVAS-MASSANA, BLANCH 2013]. Also, the use of this technology is adequate to overcome the disadvantages of conventional swimming pools, such as: high lifetime costs, more chemical use, more maintenance and high initial costs [ARROYO et al. 2015].

The technique of phytodepuration is widely used to improve the chemical-microbiological quality of NSPs. It is a simple treatment technology that only requires a pumping equipment for the water recirculation; however, the pumping system can be suppressed depending on the natu- ral pool mode. In general, for the construction of a phytodepuration system local materials are used, which constitute the support material of the filtration zone. The type of phytodepuration technique most commonly used in natural pools is the artificial wetland (AW), which consists of an area with the soil saturated with water in which a community of microorganisms adapted to aquatic life lives in association with different plant species [BERNINGER et al. 2012; GUITTONNY-PhiLipPe et al. 2014; SUltanA et al. 2014; VYMAZAL 2014; WU et al. 2015].

Nowadays, the construction of artificial wetlands is based on two systems: artificial wetlands with free water surface (AW-FWS) and artificial wetlands with sub-surface flow (AW-SSF). Free water surfaces are similar to natural wetlands, with a shallow wastewater stream circulating on a saturated substrate; while in the sub-surface flow, the wastewater flows horizontally (AW-HSSF) or vertically (AW-VSSF) in a filtering zone which allows the growth of the plants, allocated in the flow direction [JÓźWIAKOWSKI 2017; SAEED, SUN 2012]. Currently, several studies have focused on the design, development and operation of AWs, which have reported that the latter are efficient in the removal of several pollutants (organic matter, nutrients, trace elements, pharmaceutical contaminants and pathogens) on the wastewaters [BADHE et al. 2014; CUI et al. 2010; HARRINGTON, SCHOLZ 2010; MIODUSZEWSKI 2014; SAEED, SUN 2013; SKRZYPIEC, GAJEWSKA 2017; YALCUK, UGURLU 2009]. However, the suitable and sustainable operation of the AWs remains a challenge since the operational parameters are essential in the removal efficiency of the system [WU et al. 2014], but the plant species and the different filters' substrates may also have a significant influence on the elimination of pollutants [ARIAS et al. 2001; Li et al. 2008].

Current research indicates that progress has been made in the design and operation of AWs which has increased pollutant removal efficiency, as well as the sustainable application of this treatment system. For example, excellent performance of AWs has been achieved on the treatment of highly pollutant wastewaters, even in temperate environmental conditions, with an adequate mode of operation and handling of the hydraulic and organic loading rates; and with the possibility of selecting both the plants and the filter medium. Due to the increase in environmental legislations on water quality, there are still some limitations in the application of AWs for the treatment of wastewaters. Therefore, research is still required to increase the knowledge in the critical aspects of this technology. Some of these critical considerations are summarized below: i) since plants and filter media are critical factors for the adequate removal of pollutants from wastewater in AWs, the appropriate selection of macrophyte species to be used is very important because they affect the production of plant biomass, the emission rate of oxygen and carbon compounds, the removal rates of heavy metals and inorganic compounds, the tolerance to handle high loads of pollutants and the effect on the efficiency of the system not only in one season but in different seasons; ii) because the optimal operation of the AWs depends on the environmental conditions and on the hydraulic loads applied, knowing 
the appropriate settings of these two factors still demand even more in-depth studies; iii) nutrients and other contaminants assimilated by plants can be released into the water when the plants die; therefore, appropriate management strategies are required for nutrient recycling in the AWs [WU et al. 2015].

The most frequently used macrophytes species in AWs include emerged, submerged and floating plants on the water surface. Actually, there are reports of more than 150 of macrophytes species that have been used in wetlands [VYMAZAL 2013]. Among the emergent species commonly used are: Phragmites spp, Typha spp, Scirpus spp, Iris spp, Juncus spp and Eleocharis spp. The submerged plants most frequently used in the AWs are: waterthyme (Hydrilla verticillata), coontail (Ceratophyllum demersum), tape grass (Vallisneria natans), whorl-leaf watermilfoil (Myriophyllum verticillatum) and curly-leaf pondweed (Potamogeton crispus); and some the floating plants are of the species water lilies (Nymphaea tetragona), water fringe (Nymphoides peltata), water chestnut (Trapa bispinosa), European waterclover (Marsilea quadrifolia), common water hyacinth (Eichhornia crassipes), floating fern (Salvinia natans), frogbit (Hydrocharis dubia) and common duckweed (Lemnaminor) [Wu et al. 2015].

The main vegetation used in AW-FWs and AW-SSF bioreactors for wastewater treatment is emergent macrophytes. In particular, Phragmites australis is the most widely used in Europe and Asia; Typha latifolia in North America; Cyperus papyrus and Scirpus validus in Oceania; whereas, $P$. australis, and Typha domingensis are the predominat species in South America [VyMAZAL 2011]. Actually, Thypa sp., has deserved a lot of attention for its usefulness in several ecological aspects, such as improving water quality in treatment systems [COVENEY et al. 2002; GOMES et al. 2013; HeGAZY et al. 2011; SCHRODER et al. 2003], restoring the diversity in wetlands [BOERS et al. 2007; NEWMAN et al. 1996], influencing greenhouse gas emissions in wetlands [CHANTON et al. 1993; GROSS et al. 1993] and nutrients recycling [SHARMA et al. 2006].

Several European countries, for example, Spain, Portugal, Germany and Switzerland, have many years of experience in the application of phytodepuration methods with AWs for swimming pool water treatment. However, there is still no European regulatory directive for the design, construction and management of NSP; although several of them have been approved in different countries by the corresponding national health authority [MARION et al. 2010]. In Latin America, countries like Mexico, Brazil, Argentina and Colombia have entered this area, and currently several of these technologies are under development and homologation [GERALDES et al. 2014]. According to studies carried out by CASANOVAS-MASSANA and BLANCH [2013], it was emphasized that a natural purification system may be insufficient to reduce the pathogen load. For this reason, it is necessary to continue investigating this type of swimming pool in order to determine the parameters that guarantee an acceptable microbiological risk for users. Therefore, the objective of the following work was to evaluate the use of artificial wetlands with vertical sub surface flow (AW-VSSF) to treat the water of a natural swimming pool and to study the effect of the operating factors (hydraulic load and vegetation) that influence the elimination efficiency of pollutants.

\section{MATERIAL AND METHODS}

\section{CHARACTERIZATION OF THE FILTER MEDIUM}

Materials used in the filter media for the AW-VSSF bioreactors were washed sands and gravels from two quarries located in the province of Santiago de Cuba (2001'11.4" N; 7548'50.1" W), Cuba. Two volumes of $0.25 \mathrm{~m}^{3}$ of sand and gravel, respectively, were removed and deposited in polyethylene bags for transport to the laboratory. Afterwards, a small part of both materials $(10 \mathrm{~kg})$ were used for their characterization following the methodology specified in the Cuban Official Standards (NC): effective diameter, uniformity coefficient, shape factor, maximum and minimum diameters of the materials, organic impurities, specific weight and water absorption, percentage of voids, and content of clay particles. Hardness is the opposition that materials offer to external alterations, such as penetration, abrasion, scratching, shearing, and permanent deformations. The hardness of the filter material (gravels) was determined by the Mohs scale method, which consists of a hardness test based on the resistance offered by a non-metallic material to be scratched. Acid erosion was carried out by direct contact with different types of acids: hydrochloric acid $(\mathrm{HCl})$, sulfuric acid $\left(\mathrm{H}_{2} \mathrm{SO}_{4}\right)$ and nitric acid $\left(\mathrm{HNO}_{3}\right)$ for 24 hours. Then, the percentage of wear of the filter material used was determined.

\section{COLLECTION AND PREPARATION OF THE WATER TO BE TREATED}

The waters used in the biodegradation experiments were collected from different surface water sources, commonly used for recreational purposes in the territory of Santiago de Cuba. After the water was collected, it was transported in $20 \mathrm{dm}^{3}$ plastic containers to the site where the experiments were conducted.

\section{LABORATORY-SCALE BIOREACTORS}

An outline of the experimental layout used to assess the use of AWs for the treatment natural swimming pools can be seen in Figure 1. Two AW-VSSF bioreactors, called $\mathrm{R} 1$ and R2, were used in the experiments. Both bioreactors were constructed with red ceramic tubes with an internal diameter of $0.1 \mathrm{~m}$ and $1.0 \mathrm{~m}$ in height, so that the area of their cross-section and their total volume was $0.0078 \mathrm{~m}^{2}$ and $0.078 \mathrm{~m}^{3}$, respectively. The sand and gravels used in the experiments were washed with water, prior to their placement in the bioreactors. Then, disinfection with sodium hypochlorite ( $\mathrm{NaHCO}$ ) diluted at $2 \mathrm{mg} \cdot \mathrm{dm}^{-3}$ was performed for 30 minutes to avoid any possible bacterial contamination. Next, the bioreactors were washed with sterile distilled water. Inside each bioreactor was placed a granular filter bed composed in ascending order of three layers of different granulometries: the first one of $100 \mathrm{~mm}$ in 


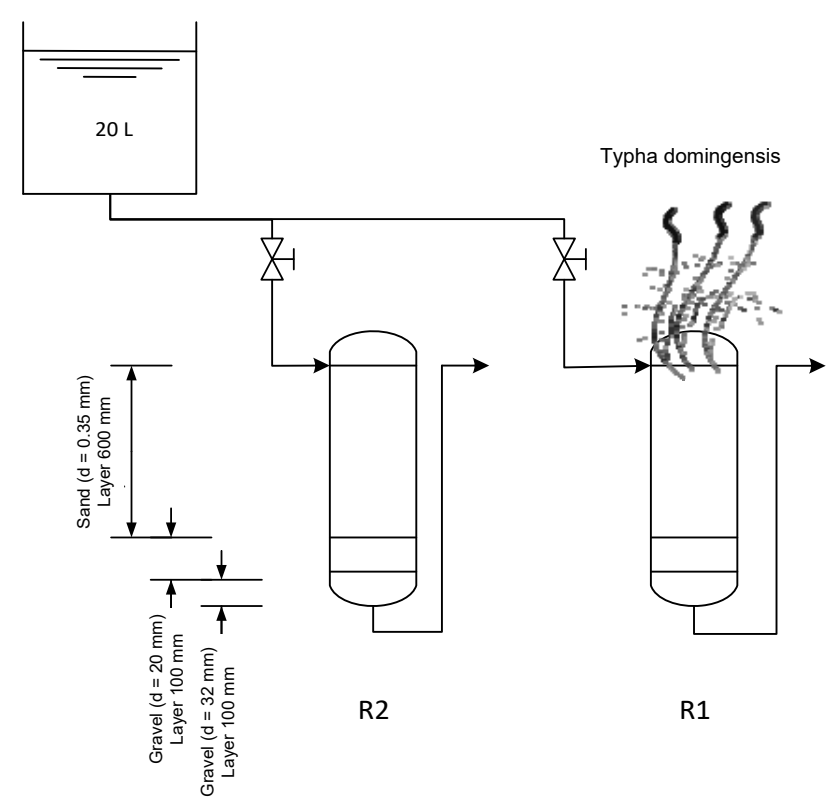

Fig. 1. Layout of the AW-VSSF bioreactors built on a laboratory scale. The vegetation used in the bioreactor on the right (R1) was Typha domingensis; bioreactor on the left (R2) had no vegetation; $d=$ substitutive grain diameter; source: own elaboration

height consisted of gravel having an effective diameter of $32 \mathrm{~mm}$; the second layer of $100 \mathrm{~mm}$ in height consisted of gravel having an effective diameter of $20 \mathrm{~mm}$; and the third layer of $600 \mathrm{~mm}$ in height consisted of washed sand with an average effective diameter of $4.76 \mathrm{~mm}, 32 \%$ of voids and whose coefficient of uniformity was 4 . The depth of the water column in both bioreactors was $0.8 \mathrm{~m}$.

In the bioreactor R1, rhizomes of Typha domingensis were planted as emergent aquatic plant; whereas in the bioreactor R2 no vegetation was planted. In each bioreactor, a high-density polyethylene (HDPE) pipe, with an internal diameter of $6.0 \mathrm{~mm}$ and a length of $1.0 \mathrm{~m}$, was installed at the bottom as an outlet conduit and for sampling. In addition, a $20 \mathrm{dm}^{3}$ capacity reservoir, having two serological hoses with their corresponding valves, supplied a constant flow and hydraulic load to the bioreactors. During the acclimatization period (30 days), both bioreactors were washed with a continuous and uniform flow rate of drinkable water for one hour a day.

\section{ACCLIMATIZATION AND GROWTH CONTROL OF Typha domingensis}

Several specimens of Typha domingensis were collected in a natural wetland near the city of Santiago de Cuba. Planting of the plant material in R1 bioreactor was performed by extracting a rhizome from the harvested plant. The rhizome was extracted with the use of a pickaxe; while the leaves were cut with scissors. The remaining vegetable material was washed with water to remove the substrate residues and disinfected with hydrogen peroxide $\left(\mathrm{H}_{2} \mathrm{O}_{2}\right)$. Once the rhizome was seeded, R1 bioreactor was maintained in a continuous and uniform irrigation regime with drinkable water free of residual chlorine for $24 \mathrm{~h}$. After this time, irrigation was carried out for $1 \mathrm{~h}$ per day. The acclimation time was adjusted to 1 month.
Once the first leaves of the Typha domingensis were visible, the plant and leave growth rate was recorded measuring the length and width of the stem and the number of leaves and their dimensions. This step allowed evaluating the adaptability of the plant to the support medium and its vegetative development in the experimental conditions. Plant growth control was performed in two stages: one at the laboratory scale and other at the pilot scale. In the first stage, vegetation growth rate, quantity and width of leaves, vegetation cover and wet weight of each plant were determined; in the second stage, the same variables were measured but in a larger surface area $\left(1 \mathrm{~m}^{2}\right)$, with the objective of assessing the development of vegetation in a pilot-scale.

\section{EXPERIMENTAL DESIGN}

The experimental design was a factorial design in which the variables to be assessed were surface hydraulic load, vegetation, water sources and samples; while, the other parameters of the model characterized the effect of the interactions between the aforementioned factors, respectively. The levels of the factors or variables assessed were defined as follows: surface hydraulic load ( 0.25 and $0.50 \mathrm{~m}^{3} \cdot \mathrm{m}^{-2} \cdot \mathrm{d}^{-1}$ ), vegetation (with vegetation and without vegetation), and 3 levels of water sources. The statistical analysis was carried out with the ANOVA procedure of the statistical package Statgraphics Centurion XV (Statpoint Technologies, 2007). Differences between main effects means, and their interactions, were assessed by a least significant difference $(L S D)$ test $(P<0.05)$.

\section{EXPERIMENTAL PROCEDURE}

After a period of acclimatization of 30 days, considering this time necessary for the growth of the vegetation in $\mathrm{R} 1$ bioreactor and for the formation of biofilms of microorganisms in R2 bioreactor, the evaluation of the different conditions of the experiment was initiated. The bioreactors were filled in two consecutive days with the water collected from the sources, applying continuously a water flow between $0.002-0.004 \mathrm{~m}^{3} \cdot \mathrm{h}^{-1}$ during $8 \mathrm{~h} \cdot$ day $^{-1}$. These values range agree with the designing criteria for multiple and slow filters of sands used for water disinfection [USEPA 2000]. The samples for the physical-chemical and microbiological indicators of the waters treated were carried out in duplicated; samples of the effluent treated was collected every week during 1 month.

\section{PHYSICAL-CHEMICAL AND MICROBIOLOGICAL CHARACTERIZATION OF THE WATERS}

The physical-chemical and microbiological characterization of the waters used in the experiments was completed according to the Standard Methods for the Examination of Water and Wastewaters [APHA 1995]. The analyses of the water samples used were performed in the Laboratory of the National Institute of Hydraulic Resources (INRH) and in the Center of Studies of Industrial Biotechnology (University of Oriente, Cuba). Concentrations of chemical oxygen demand (COD) and biological oxygen demand (BOD), nitrates, ammonia and $\mathrm{pH}$ were determined. The determi- 
nation of total and faecal coliforms was done in the Laboratorio de Higiene y Epidemiología del Ministerio de Salud Pública (MINSAP), Santiago de Cuba, following the procedure of counting by dilution (number more probable). To differentiate the bacterial populations of total coliforms from those of faecal coliforms, the water samples were incubated during fermentation of the lactose at $37^{\circ} \mathrm{C}$ and $44^{\circ} \mathrm{C}$, respectively [MCCRADY 1915].

\section{RESULTS AND DISCUSSION}

\section{PHYSICAL-CHEMICAL AND MECHANICAL CHARACTERIZATION OF THE FILTER MEDIA}

The different components characterizing the sand used in the filter bed of the bioreactors were: $43 \%$ quartz; $27 \%$ feldspar; $5 \%$ calcite; $13 \%$ montmorillonite minerals; and $5 \%$ of rock remains. According to the standard used, this type of sand is defined as natural, i.e. sand that comes from the natural disintegration of the rocks. Resistance to the compression showed minimum and maximum values of 800 and $1200 \mathrm{~kg} \cdot \mathrm{cm}^{-2}$, respectively. Dry saturated weight was $2.55 \mathrm{~g} \cdot \mathrm{cm}^{-3}$, wet saturated weight $2.61 \mathrm{~g} \cdot \mathrm{cm}^{-3}$ and the absorption $2.8 \%$. The swelling coefficient ranged from 1.5 to 1.8 , with a hardness of 6 according to Mohs scale. Tab le 1 shows the wear percentage of the gravels used in the filter bed after being exposed to the action of different acids for 24 hours. Gravel with a mean effective diameter of $32 \mathrm{~mm}$ had the highest percentage of wear, $15.5 \%$, when diluted with hydrochloric acid $(\mathrm{HCl})$, while the lowest percentage of wear, $1.71 \%$, was that of gravel with a mean effective diameter of $20 \mathrm{~mm}$ when diluted with nitric acid $\left(\mathrm{HNO}_{3}\right)$. Both values were considered acceptable for being

Table 1. Wear percentage of filter media (gravels)

\begin{tabular}{|l|l|c|c|c|}
\hline \multirow{3}{*}{ Grain diameter } & \multicolumn{1}{|c|}{$\begin{array}{c}\text { Acids } \\
\text { (diluted to 5\%) }\end{array}$} & $\begin{array}{c}\text { Initial } \\
\text { weight } \\
(\mathrm{g})\end{array}$ & $\begin{array}{c}\text { Final } \\
\text { weight } \\
(\mathrm{g})\end{array}$ & $\begin{array}{c}\text { Wear } \\
(\%)\end{array}$ \\
\hline \multirow{3}{*}{$20 \mathrm{~mm}$} & hydrochloric acid $(\mathrm{HCl})$ & 11.792 & 10.794 & 8.97 \\
\cline { 2 - 5 } & sulfuric acid $\left(\mathrm{H}_{2} \mathrm{SO}_{4}\right)$ & 28.836 & 28.155 & 2.36 \\
\cline { 2 - 5 } & nitric acid $\left(\mathrm{HNO}_{3}\right)$ & 22.850 & 22.460 & 1.71 \\
\hline \multirow{3}{*}{$32 \mathrm{~mm}$} & $\mathrm{HCl}$ & 30.000 & 25.500 & 15.50 \\
\cline { 2 - 5 } & $\mathrm{H}_{2} \mathrm{SO}_{4}$ & 30.000 & 28.365 & 5.45 \\
\cline { 2 - 6 } & $\mathrm{HNO}_{3}$ & 30.000 & 29.250 & 2.50 \\
\hline
\end{tabular}

Source: own study. used as filter media. This material is quite resistant to the action of acids and to all sort of mechanical actions, because they are granitoid materials and they are considered as hard, hardness of 6 in the scale of Mohs. This feature makes it a suitable material to be used as filter media in wetlands; for this reason, it has been recommended by the United States Environmental Protection Agency [USEPA 2000].

The diameter of the particles is one of the main parameters that influence the effectiveness of the filtration or the retention of suspended solids in the AWs. Fine aggregates, such as sand, with an effective diameter between 0.25-2.0 $\mathrm{mm}$, are the most used media filters in the elimination of pathogens and nutrients. However, they tend to reduce the porous space, making it difficult for water to pass through and are prone to clogging the filter [BRIX, ARIAS 2005]. On the other hand, coarse gravel, with effective diameters greater than $2.0 \mathrm{~mm}$, allows pores to be larger, water to drain without any difficulty and the filter not to be easily clogged [KNOWLES et al. 2011]; but the surface area in the upper layers of the filter medium is inadequate for the growth of the microbial biofilm.

There are other materials, such as zeolite and activated carbon, for example, which have a diameter similar to sand but with a porous structure that ensures a large surface area for the development of biofilms. The greater this surface area, the greater the capacity of adsorption and desorption of pollutants from wastewater [DORDIO, CARVALHO 2013]. Another important factor to consider is the hardness of the material that constitutes the filter medium. Hard materials, with values higher than 6 on the Mohs scale, are able to withstand the physical actions of sieving and the impacts due to inertial effects during the filtration process. Likewise, clay has been used in AW-SSF with promising results in the removal of metals and pathogenic microorganisms present in industrial wastewater [GONZÁLEZ 2006].

\section{CHARACTERIZATION OF THE WATERS USED}

The characterization of the water used in the laboratory experiments is shown in Table 2 . A wide variability was observed in the chemical parameters of the sampled waters, depending on the influx of people to these water sources and the actual flow of the sources. As these factors

Table 2. Characterization of waters used for laboratory tests using WA-VSSF bioreactors

\begin{tabular}{|c|c|c|c|c|c|c|c|c|c|}
\hline \multirow[t]{2}{*}{ Parameter } & \multirow[t]{2}{*}{ Unit } & \multicolumn{2}{|c|}{$\begin{array}{l}\text { Natural waterfall } \\
\text { Juan González }\end{array}$} & \multicolumn{2}{|c|}{ Carpintero river } & \multicolumn{2}{|c|}{$\begin{array}{c}\text { Porvenir swimming } \\
\text { pool } \\
\end{array}$} & \multirow{2}{*}{$\begin{array}{l}\text { Average } \\
\text { value }\end{array}$} & \multirow{2}{*}{$\begin{array}{l}\text { Standard } \\
\text { deviation }\end{array}$} \\
\hline & & M1 & M2 & M1 & M2 & M1 & M2 & & \\
\hline \multicolumn{10}{|c|}{ Chemical characteristics } \\
\hline BOD & $\mathrm{mg} \cdot \mathrm{dm}^{-3}$ & 2 & 5 & 7 & 6 & 6 & 2.5 & 4.75 & \pm 2.0 \\
\hline COD & $\mathrm{mg} \cdot \mathrm{dm}^{-3}$ & 8 & 18 & 22 & 21 & 22 & 9,6 & 16.7 & \pm 6.4 \\
\hline Nitrate & $\mathrm{mg} \cdot \mathrm{dm}^{-3}$ & 0.5 & 0.85 & $<2.08$ & $<2.08$ & $<2.08$ & 2.5 & 1.7 & \pm 0.8 \\
\hline Ammonia & $\mathrm{mg} \cdot \mathrm{dm}^{-3}$ & 0.6 & 1.25 & 7.63 & 7.87 & 7.9 & 2.5 & 4.6 & \pm 3.5 \\
\hline $\mathrm{pH}$ & - & 7.5 & 7.5 & 7.5 & 7.5 & 8.0 & 7.0 & 7.5 & \pm 0.1 \\
\hline \multicolumn{10}{|c|}{ Bacteriological characteristics } \\
\hline Total coliforms & $\operatorname{NMP} \cdot\left(0.1 \mathrm{dm}^{3}\right)^{-1}$ & 11 & 50 & 1600 & 1600 & 350 & 234 & 640 & \pm 753 \\
\hline Faecal coliforms & $\mathrm{NMP} \cdot\left(0.1 \mathrm{dm}^{3}\right)^{-1}$ & 6 & 0 & 600 & 4 & 50 & 4 & 342 & \pm 629 \\
\hline
\end{tabular}

Explanations: $\mathrm{BOD}=$ biological oxygen demand, $\mathrm{COD}=$ chemical oxygen demand.

Source: own study. 
are difficult to control in natural conditions, their management requires an efficient and versatile self-purification system that does not entail an aggressive intervention of the landscape environment in which they are located.

In all the samples, the $\mathrm{pH}$ values were close to the neutral range (7.0-7.5). These $\mathrm{pH}$ values favour the growth of a wide variety of microorganisms that support the biochemical processes of biodegradation. The presence of organic matter, nitrogen compounds and microorganisms of the coliform group is due usually to the anthropic action to which these aquariums are subjected, since human secretions, faecal or not, are potential sources of pathogenic microorganisms [CDC 2001; 2004; CRAUN et al. 1997; FIORILLO et al. 2001; HILDEBRAND et al. 1996; KRAMER et al. 1996; LEVY et al. 1998; SINCLAIR et al. 2009; TIRODIMOS et al. 2010; YODER et al. 2004]. Even when low concentrations of chemical contaminants are observed in the collected waters, they lack the microbiological quality required for bathing [NC-22 1999]. The removal of pathogenic microorganisms is one of the main objectives in the guidelines established by the World Health Organization (WHO). A sample of each of these selected water sources was used to feed the WA-VSSF bioreactors at laboratory scale to simulate the operation of the NSP treatment system.

\section{REMOVAL OF ORGANIC POLLUTANTS}

The efficiency in the elimination of organic pollutants can be seen in Table 3. The results of the ANOVA show that factors such as hydraulic loading and vegetation influenced the removal efficiency of COD, BOD, nitrates and ammonia. Significant differences were also detected among the water sources selected, as well as between the two samples, as expected.

Figure 2 shows the average concentrations of BOD, COD, nitrate and ammonium in the effluent of the bioreactors studied. The presence of vegetation (R1), in all cases,

Table 3. ANOVA for the removal efficiency of organic pollutants

\begin{tabular}{|l|r|c|r|r|l|}
\hline $\begin{array}{c}\text { Variability } \\
\text { sources }\end{array}$ & $\begin{array}{c}\text { Sum of } \\
\text { squares } \\
\text { (SS) }\end{array}$ & df & $\begin{array}{c}\text { Middle } \\
\text { squares } \\
\text { (MS) }\end{array}$ & $F$-value & $p$-value \\
\hline \multicolumn{7}{|c|}{ BOD } \\
\hline A: H. loading rate & 0.5055 & 1 & 0.5055 & 23.92 & $0.0000^{*}$ \\
\hline B: Vegetation & 0.8070 & 1 & 0.8070 & 38.18 & $0.0000^{*}$ \\
\hline C: Water sources & 68.3193 & 2 & 34.1597 & 1616.13 & $0.0000^{*}$ \\
\hline D: Samples & 4.5596 & 1 & 4.5596 & 215.72 & $0.0000^{*}$ \\
\hline AB & 0.0431 & 1 & 0.0430 & 2.04 & 0.1628 \\
\hline AC & 0.2781 & 2 & 0.1390 & 6.58 & $0.0039^{*}$ \\
\hline AD & 0.0005 & 1 & 0.0005 & 0.02 & 0.8810 \\
\hline BC & 0.0432 & 2 & 0.0216 & 1.02 & 0.3704 \\
\hline BD & 0.0137 & 1 & 0.0136 & 0.65 & 0.4271 \\
\hline CD & 60.6447 & 2 & 30.3224 & 1434.58 & $0.0000^{*}$ \\
\hline Residual & 0.6975 & 33 & 0.0211 & & \\
\hline Total (corrected) & 135.912 & 47 & & & \\
\hline \multicolumn{7}{|c|}{ COD } \\
\hline A: H. loading rate & 1.9012 & 1 & 1.9012 & 25.81 & $0.0000^{*}$ \\
\hline B: Vegetation & 4.2346 & 1 & 4.2346 & 57.49 & $0.0000^{*}$ \\
\hline C: Water sources & 588.965 & 2 & 294.4830 & 3998.26 & $0.0000^{*}$ \\
\hline D: Samples & 12.6557 & 1 & 12.6557 & 171.83 & $0.0000^{*}$ \\
\hline AB & 0.0635 & 1 & 0.0635 & 0.86 & 0.3596 \\
\hline
\end{tabular}

\begin{tabular}{|c|c|c|c|c|c|}
\hline $\mathrm{AC}$ & 1.0364 & 2 & 0.5182 & 7.04 & $0.0028^{*}$ \\
\hline $\mathrm{AD}$ & 0.0022 & 1 & 0.0022 & 0.03 & 0.8647 \\
\hline $\mathrm{BC}$ & 1.6084 & 2 & 0.8042 & 10.92 & $0.0002 *$ \\
\hline $\mathrm{BD}$ & 2.5084 & 1 & 2.5084 & 34.06 & $0.0000^{*}$ \\
\hline$\overline{\mathrm{CD}}$ & 877.967 & 2 & 438.9840 & 5960.18 & $0.0000^{*}$ \\
\hline Residual & 2.4305 & 33 & 0.07365 & & \\
\hline Total (corrected) & 1493.37 & 47 & & & \\
\hline \multicolumn{6}{|c|}{ Nitrate } \\
\hline A: H. loading rate & 0.0004 & 1 & 0.0004 & 16.39 & $0.0003^{*}$ \\
\hline B: Vegetation & 0.0009 & 1 & 0.0009 & 32.13 & 0.0000* \\
\hline C: Water sources & 17.5684 & 2 & 8.7841 & 307155.91 & $0.0000^{*}$ \\
\hline D: Samples & 1.0591 & 1 & 1.0591 & 37033.50 & $0.0000^{*}$ \\
\hline $\mathrm{AB}$ & 0.0000 & 1 & 0.000002 & 0.07 & 0.7889 \\
\hline $\mathrm{AC}$ & 0.0003 & 2 & 0.00015 & 5.46 & 0.0089* \\
\hline $\mathrm{AD}$ & 0.0000 & 1 & 0.00005 & 1.82 & 0.1864 \\
\hline $\mathrm{BC}$ & 0.0004 & 2 & 0.0002 & 8.09 & 0.0014* \\
\hline $\mathrm{BD}$ & 0.0001 & 1 & 0.0001 & 3.57 & $0.0677 * *$ \\
\hline $\mathrm{CD}$ & 4.8881 & 2 & 2.4440 & 85462.21 & $0.0000^{*}$ \\
\hline Residual & 0.0009 & 33 & 0.00002 & & \\
\hline Total (corrected) & 23.5189 & 47 & & & \\
\hline \multicolumn{6}{|c|}{ Ammonia } \\
\hline A: H. loading rate & 0.0198 & 1 & 0.0198 & 25.35 & $0.0000^{*}$ \\
\hline B: Vegetation & 0.0570 & 1 & 0.0570 & 73.03 & $0.0000^{*}$ \\
\hline C: Water sources & 371.3220 & 2 & 185.6610 & 237621.92 & $0.0000^{*}$ \\
\hline D: Samples & 31.0972 & 1 & 31.0972 & 39800.33 & $0.0000^{*}$ \\
\hline $\mathrm{AB}$ & 0.0005 & 1 & 0.0005 & 0.64 & 0.4292 \\
\hline$\overline{\mathrm{AC}}$ & 0.0033 & 2 & 0.0016 & 2.11 & 0.1368 \\
\hline $\mathrm{AD}$ & 0.0003 & 1 & 0.0003 & 0.49 & 0.4906 \\
\hline $\mathrm{BC}$ & 0.0120 & 2 & 0.0060 & $\begin{array}{ll}7.68 \\
\end{array}$ & $0.0018^{*}$ \\
\hline $\mathrm{BD}$ & 0.0024 & 1 & 0.0024 & 3.17 & $0.0840 * *$ \\
\hline CD & 89.4946 & 2 & 44.7473 & 57270.74 & $0.0000^{*}$ \\
\hline Residual & $\begin{array}{l}0.0257 \\
\end{array}$ & 33 & 0.0008 & & \\
\hline Total (corrected) & 492.0350 & 47 & & & \\
\hline \multicolumn{6}{|c|}{ Total coliforms } \\
\hline A: H. loading rate & 184.08 & 1 & 184.08 & 21.14 & $0.0001 *$ \\
\hline B: Vegetation & 0.75 & 1 & 0.75 & 0.09 & 0.7710 \\
\hline C: Water sources & 1729.50 & 2 & 864.75 & 99.29 & $0.0000^{*}$ \\
\hline D: Samples & 2268.75 & 1 & 2268.75 & 260.49 & $0.0000^{*}$ \\
\hline $\mathrm{AB}$ & 0.75 & 1 & 0.75 & 0.09 & 0.7710 \\
\hline $\mathrm{AC}$ & 282.16 & 2 & 141.08 & 16.20 & $0.0000^{*}$ \\
\hline $\mathrm{AD}$ & 184.08 & 1 & 184.08 & 21.14 & $0.0001^{*}$ \\
\hline $\mathrm{BC}$ & 1.50 & 2 & 0.75 & 0.09 & 0.9177 \\
\hline $\mathrm{BD}$ & 0.75 & 1 & 0.75 & 0.09 & 0.7710 \\
\hline $\mathrm{CD}$ & 1729.50 & 2 & 864.75 & \begin{tabular}{|c|}
99.29 \\
\end{tabular} & $0.0000^{*}$ \\
\hline Residual & 287.41 & 33 & 8.71 & & \\
\hline Total (corrected) & 6669.25 & 47 & & & \\
\hline \multicolumn{6}{|c|}{ Faecal coliforms } \\
\hline A: H. loading rate & 884.08 & 1 & 884.08 & \begin{tabular}{|c|}
46.80 \\
\end{tabular} & $0.0000^{*}$ \\
\hline B: Vegetation & 10.08 & 1 & 10.08 & 0.53 & 0.4702 \\
\hline C: Water sources & 5805.17 & 2 & 2902.58 & 153.65 & $0.0000 *$ \\
\hline D: Samples & 70.08 & 1 & 70.08 & 3.71 & $0.0627 * *$ \\
\hline $\mathrm{AB}$ & 6.75 & 1 & 6.75 & 0.36 & 0.5541 \\
\hline $\mathrm{AC}$ & 452.16 & 2 & 226.08 & 11.97 & $0.0001^{*}$ \\
\hline $\mathrm{AD}$ & 6.75 & 1 & 6.75 & 0.36 & 0.5541 \\
\hline $\mathrm{BC}$ & 5.17 & 2 & 2.58 & 0.14 & 0.8727 \\
\hline $\mathrm{BD}$ & 2.08 & 1 & 2.08 & 0.11 & 0.7419 \\
\hline $\mathrm{CD}$ & 4886.17 & 2 & 2443.08 & 129.32 & $0.0000^{*}$ \\
\hline Residual & 623.41 & 33 & 18.8914 & & \\
\hline Total (corrected) & 12751.90 & 47 & & & \\
\hline
\end{tabular}

Explanations: $\mathrm{df}=$ degrees of freedom, $\mathrm{BOD}=$ biological oxygen demand, $\mathrm{COD}=$ chemical oxygen demand, $\mathrm{H}$. loading rate $=$ hydraulic loading rate.

$* p$-values $<0.05$ were considered to be significant $(95 \%)$.

$* * p$-values $<0.1$ were considered to be significant $(90 \%)$.

Source: own study. 
a)
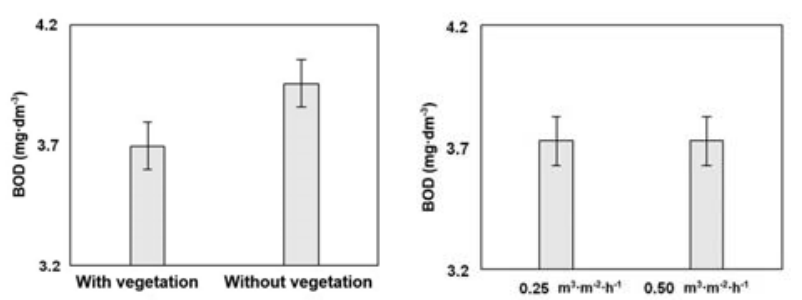

b)
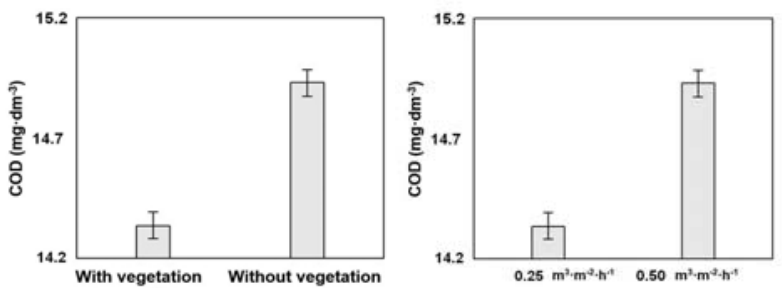

c)

d)

e)

f)
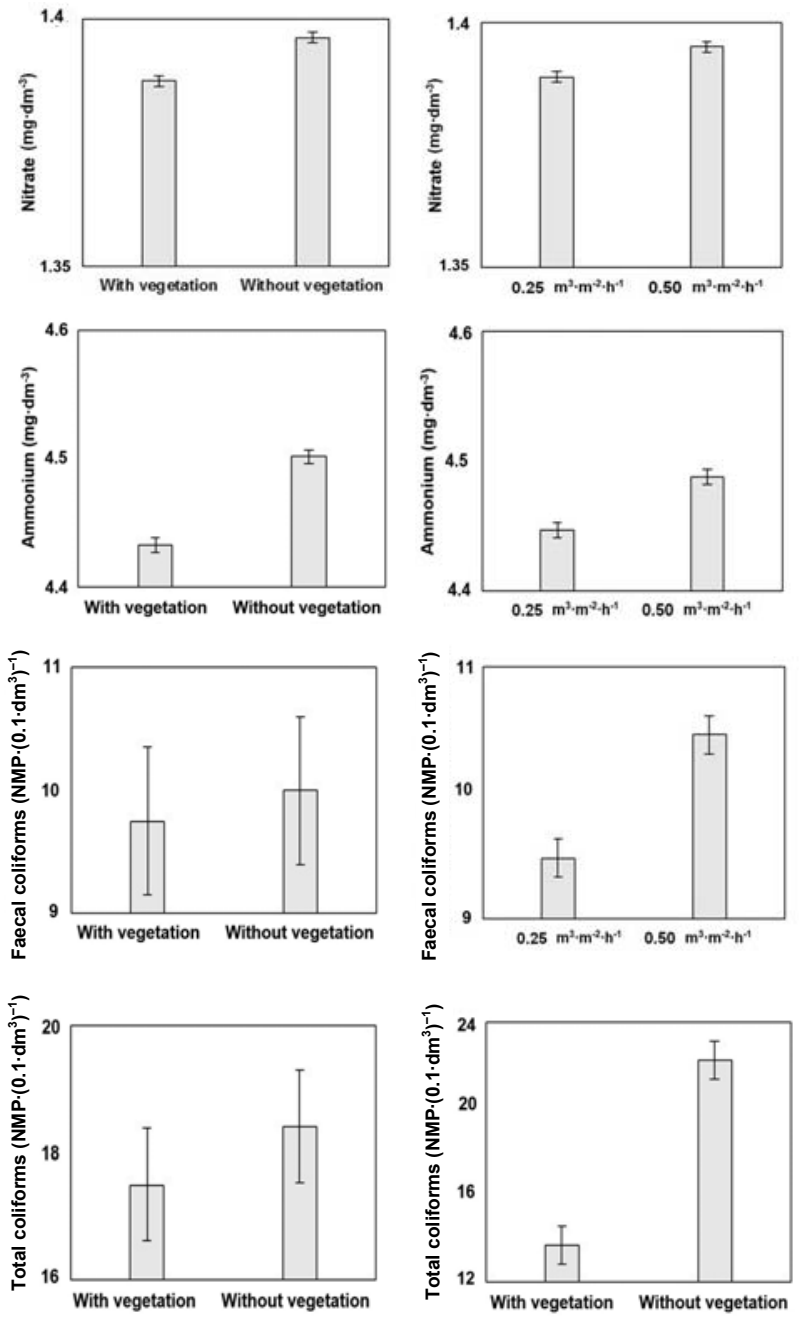

Fig. 2. Performance of the AW-VSSF bioreactors evaluated: a) BOD, b) COD, c) nitrate, d) ammonium, e) faecal coliforms, f) total coliforms; source: own study

favoured the reduction of nitrogen compounds (nitrates and ammonia) and organic materials (BOD and COD). This fact is explained by the presence of assimilation processes of organic compounds, or by the action of microorganisms associated with the rhizome of the Typha plants, which establish a favourable symbiotic mechanism for phytodepuration. The lowest concentration of ammonium obtained in $\mathrm{R} 2$ reached a value of $2.15 \mathrm{mg} \cdot \mathrm{dm}^{-3}$, which is within the limits allowed by sanitary regulations [NC-22 1999].

The elimination of COD was 4 times lower in $\mathrm{R} 2$ than in $\mathrm{R} 1$, with average values of $2.6 \%$ and $10 \%$, respectively. Similarly, it can be seen in Figure 2 that the removal of pollutant compounds decreased in the following order: $\mathrm{NH}_{4}{ }^{+} 31 \%>\mathrm{NO}_{3}{ }^{-} 20 \%$ and $\mathrm{BOD} 16 \%>\mathrm{COD}>10 \%$. These figures suggest that the presence of oxidized nitrogen species limits the ability to remove contaminants unless phytodepuration is incorporated into the wetland as a treatment system. In comparison with the results obtained by GONZÁLEZ [2006], our findings suggest that the pollutant removal achieved by the AWs is less evident. Nevertheless, results similar to those obtained in this study were reported by KOUKIA et al. [2009], who assessed the operation of a combined AW-FWS and AW-SSF wetland system designed for rural domestic wastewaters treatment.

Increasing the applied hydraulic load, a significant reduction in COD was observed (Fig. 2b). For example, in the first week of evaluation of R1, and for a hydraulic load of $0.25 \mathrm{~m}^{3} \cdot \mathrm{m}^{-2} \cdot \mathrm{h}^{-1}$, an average concentration in the effluent of $3.55 \mathrm{mg}$ BOD $\cdot \mathrm{dm}^{-3}$ was obtained, which implied a $25.7 \%$ of removal; and when the hydraulic load increased to $0.5 \mathrm{~m}^{3} \cdot \mathrm{m}^{-2} \cdot \mathrm{h}^{-1}$, the effluent had a concentration of 14.1 $\mathrm{mg}$ COD $\cdot \mathrm{dm}^{-3}$, which denoted a removal of $16 \%$. Both reactors exhibited low removal efficiency in comparison with other treatment systems; nevertheless, wetlands allow the treatment of waste water having pollutant concentrations less than $1.0 \mathrm{mg} \cdot \mathrm{dm}^{-3}$, in spite of the limitations of these systems.

By increasing the applied hydraulic loads, a reduction in COD and BOD removal values was observed (Fig. 2a, b). However, R1 obtained better efficiency values compared with R2. In the first week of evaluation of R1, and for a hydraulic load of $0.25 \mathrm{~m}^{3} \cdot \mathrm{m}^{-2} \cdot \mathrm{h}^{-1}$, values of average BOD concentration in the effluent of $3.55 \mathrm{mg} \cdot \mathrm{dm}^{-3}$ (removal of $25.7 \%$ ) were obtained. Also, by increasing the load to $0.5 \mathrm{~m}^{3} \cdot \mathrm{m}^{-2} \cdot \mathrm{h}^{-1}$, a COD removal of $16 \%$ was achieved, reaching concentrations in the effluent of 14.1 $\mathrm{mg}$ COD $\cdot \mathrm{dm}^{-3}$. For both bioreactors, the removal efficiency was low compared with other treatment systems; however, wetlands allow the treatment of low-load wastewater, less than $1.0 \mathrm{~g} \cdot \mathrm{dm}^{-3}$, where some of these systems have their limitations.

The mechanism of ammonium removal in AWs has been previously described by AUSTIN [2006]. In the first stage, when the wetlands receive the water to be treated, ammonium cations $\left(\mathrm{NH}_{4}{ }^{+}\right)$are retained on the negatively charged surfaces of the filter medium and then transported to the rhizomes of the plants. In the second stage, nitrate anions $\left(\mathrm{NO}_{3}{ }^{-}\right)$are formed as products of ammonium oxidation, using the organic carbon of the feed water. Plants play an important role in all treatment processes with wetlands since they are useful for the absorption of nutrients and microbial adherence. In addition, nitrate elimination mechanisms in AWs are also related to the growth of plants and the nitrification process. Denitrification is the predominant mechanism in wetlands, especially when nitrate concentrations in wastewaters are high. This occurs in the anoxic sediment zones and in the anoxic microsites of 
the biofilms adhered to the plants or the filter medium. For this reason, nitrate is one of the pollutants that is most efficiently removed using wetland systems [CUI et al. 2010]. Figure 2 shows the average concentrations of nitrate removal obtained in the effluent of the bioreactors studied. In $\mathrm{R} 1$, and for both hydraulic loads, nitrate concentrations were similar (average value of $1.4 \mathrm{mg} \cdot \mathrm{dm}^{-3}$ ). However, in the last week of evaluation, and for the lower hydraulic load applied, a lower value of nitrate removal was reached $\left(0.915 \mathrm{mg} \cdot \mathrm{dm}^{-3}\right)$. Nitrogen is an essential nutrient for plants which remains in its organic form in the vegetation of AWs; although a portion of these nutrients is returned to the system when the plants die and decompose [DEBUSK 1999]. The biodegradation of chemical compounds often involves a series of biochemical reactions, and generally varies with the microorganisms present in the process [FAULWETTER et al. 2009; VYMAZAL 2007].

Control of the growth of $T$. domingensis was carried out in R1, where some parameters of plant growth were selected: rate of growth, number and width of the leaves, vegetation cover and wet weight of each emerged plant. Figure 3 shows the growth of $T$. domingensis. During the first week of system operation, plant sprouts emerged. After 30 days, the rate of growth of the plants was constant $\left(0.24 \mathrm{~m} \cdot \mathrm{week}^{-1}\right)$ and their height $0.95 \mathrm{~m}$. At this time the first tiller emerged, the growth rate decreased to 0.07 $\mathrm{m} \cdot$ week $^{-1}$, the plants reached a length of $1.60 \mathrm{~m}$ and they had 12 leaves with an average width of $0.011 \mathrm{~m}$. At the conclusion of the experiment, five leaves of each plant in R1 withered, but a density of 3 plants per rhizome was observed covering a surface area of $0.025 \mathrm{~m}^{2}$. According to the criteria proposed by GONZÁLEZ [2000], the optimal coverage of AW-SSF reactors is reached when there are 4 plants per square meter of the wetland surface. Although the reactor had a high density of plants, no clogging of the filter was observed. The root system reached a depth of $0.35 \mathrm{~m}$, and the wet weight of each plant was $250 \pm 25 \mathrm{~g}$.

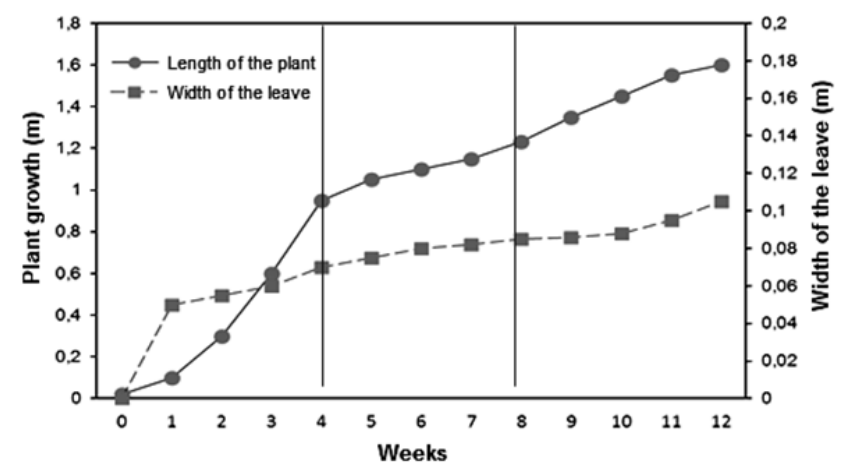

Fig. 3. Growth of T. domingensis in R1; source: own study

In order to study the vegetative behaviour of $T$. domingensis as plant material in AWs treating waters of NSPs, another bioreactor (R3) of larger scale $\left(1.0 \mathrm{~m}^{2}\right)$ was used, but with similar characteristics of its filter medium to that of R1. A surface hydraulic load of $0.25 \mathrm{~m}^{3} \cdot \mathrm{m}^{-2} \cdot \mathrm{h}^{-1}$ was established and fed to R3 discontinuously during one year. The values of vegetation growth rate, number and width of leaves, vegetation cover and wet weight of each plant were tabulated. Four rhizomes were planted in R3 and after the first 8 days of operation the buds began to sprout. Thirty days from plantation, the plants had a constant growth rate of $0.35 \mathrm{~m} \cdot \mathrm{week}^{-1}$, figure that is higher than that observed in R1. This growth behaviour was kept constant until day 105 from plantation. The parameters of vegetative growth during the first three months of operation of the reactors were very similar in R3 and R1. One year after the start-up of the bioreactors, the average height of the plants in R3 was higher than that of the R1 plants, $1.65 \mathrm{~m}$ and $0.95 \mathrm{~m}$, respectively. Similarly, the total coverage observed in R3 was 20 plants per square meter; having an average of 16 leaves per plant with an average width $0.015 \mathrm{~m}$. This coverage did not alter the water flow in the reactor. In R3 the wet weight of each plant was $275 \pm 21 \mathrm{~g}$ and the root system had an average length of $0.55 \mathrm{~m}$. These two last figures were higher than those observed in R1 plants.

With the objective of comparing the extent to which the Typha domingensis plants of the experiments had an adequate growth, Typha $s p$. plants from two different environments were selected: a natural wetland and an artificial wetland used for the treatment of domestic wastewater. In the former wetland, the average height of the plants was $1.8 \mathrm{~m}$, value similar to that obtained in the R3 treatment. In the latter wetland the average height of the plants reached $2.15 \mathrm{~m}$, their leaves had an average width of $0.02 \mathrm{~m}$, and the average coverage density was 64 plants per square meter. These results indicate that the degree of contamination of a wetland can be estimated by simply observation of the number of plants present in it and what is their vegetative growth. Thypa $s p$. is an emergent aquatic plant that grows in tropical and temperate climatic regions, has a vigorous vegetative growth thanks to the presence of perennial rhizomes in its submerged stems [EID et al. 2012]. However, systematic pruning and the annual harvest are highly recommended.

\section{MICROBIOLOGICAL QUALITY OF TREATED WATER}

The concentrations of faecal and total coliform in the treated wastewater can be seen in Figure 2e-f. The significant differences observed in the factors affecting to both variables (Tab. 3) determined the microorganism removal efficiency of the phytodepuration process. The presence of vegetation showed no significant differences in the removal of faecal and total coliforms in comparison with the removal obtained with no vegetation. Therefore, the microbiological quality of the water treated in the first system was attributed to mechanisms of adsorption-filtration and predation. These two mechanisms are present in slow sand filters used in the disinfection of water for human consumption and they are closely related to the design criteria of the two reactors used in our experiment. However, increasing the hydraulic load applied to both bioreactors resulted in a decrease of the removal efficiency (Fig. 2e-f). For example, the total coliform concentration of the effluent in $\mathrm{R} 1$, when the surface hydraulic load was $0.25 \mathrm{~m}^{3} \cdot \mathrm{m}^{-2} \cdot \mathrm{h}^{-1}$, was lower than 8 NMP per $0.1 \mathrm{dm}^{3}$, value that implies a removal efficiency of $92.5 \%$, and the concentration of faecal coliforms was below 13 NMP per $0.1 \mathrm{dm}^{3}$, value that rep- 
resents $90 \%$ of removal. The largest concentrations of faecal and total coliforms observed in the effluent of both bioreactors were below the threshold of $100 \mathrm{NMP}$ per $0.1 \mathrm{dm}^{3}$ established by the standard NC-22 [1999].

In a study conducted by CASANOVAS-MASSANA, BLANCH [2013], faecal microbial populations associated with four ecological pools were characterized. Three of the four pools evaluated exceeded the limits established for E.coli and enterococci, but the concentration of Pseudomonas aeruginosa and aerobic heterotrophic bacteria were in an acceptable range. They concluded his work affirming that the wildlife might be an important contributor of faecal contamination in NSPs. Some studies have shown that there is a significant tendency for clustering between E. coli and enterococci populations [MARION et al. 2010; WADE et al. 2006]. Likewise, studies on inland recreational waters have shown significant trends between increased gastrointestinal illnesses and E. coli or enterococci. In contrast, other authors have reported correlations between gastrointestinal illnesses and the number of swimmers, and no correlations between illnesses and faecal bacterial indicators, highlighting the importance of swimmer-to-swimmer transmission. Therefore, the relationship between health risks and faecal indicators concentrations is still under discussion [CASANOVAS-MASSANA, BLANCH 2013; COLFORD et al. 2007].

\section{EVALUATION OF A FULL-SCALE NATURAL SWIMMING POOL}

Once the laboratory experiments were completed, the operating conditions of a full-scale NSP swimming pool for recreational purposes were evaluated. The bathing zone had an area of $350 \mathrm{~m}^{2}$ and an average depth of $0.7 \mathrm{~m}$. The surface planned for phytodepuration occupied an area of $120 \mathrm{~m}^{2}$, planted all of it with Typha domingensis on a filter bed with the same operating characteristics as those of bioreactors R1 and R3. Due to the time constraints to conclude this experiment, it was not possible to wait for the vegetation to develop completely, since the rhizomes of Typha domingensis had recently been planted. Therefore, the sanitary quality of the pool water was evaluated taking as reference one of the days with the largest number of visitors. The test was conducted in two sessions: during the morning opening hours, between 10:00 a.m. and 12:00 p.m., with a total of 250 bathers, and in the afternoon, between 2:00 p.m. and 5:00 pm, with the presence of 150 bathers (Tab. 4). In both bathing sessions, the values of some of the parameters that determine the quality of the water were measured, i.e.: $\mathrm{pH}$, transparency, turbidity, residual free chlorine, nitrates, using a quick kit package (GPS Multi-Parameter Portable Water Quality Meter - HI 9829-00042).

In the morning session, the $\mathrm{pH}$ had an average value of 7.5 , whereas in the late session the average value increased to a value of 7.74. These two $\mathrm{pH}$ values did not show any significant difference and were within the range considered acceptable (6.5-8.0). Similarly, both values were lower, and with a tendency towards neutrality, than the average value of 8.77 reported by GERALDES, BOAVIDA [2004], who assessed the growth rate of zooplankton and filamen-
Table 4. Monitoring of the control parameters to the full-scale NSP

\begin{tabular}{|c|c|c|c|c|c|c|c|c|}
\hline$\stackrel{\Xi}{g}$ & 吉 & 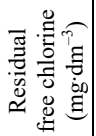 & 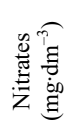 & 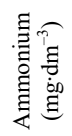 & 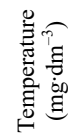 & 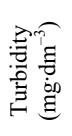 & 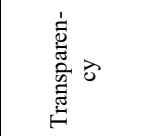 & 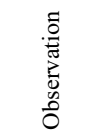 \\
\hline $\begin{array}{c}10: 00 \\
\text { a.m. }\end{array}$ & 7 & 1.5 & - & - & - & - & $\begin{array}{c}\text { the coin at } \\
1.0 \mathrm{~m} \text { deep } \\
\text { was observed }\end{array}$ & $\begin{array}{c}\text { service } \\
\text { opening } \\
\text { with } 250 \\
\text { bathers } \\
\end{array}$ \\
\hline $\begin{array}{c}\text { 11: } 00 \\
\text { a.m. }\end{array}$ & 7.5 & - & - & - & - & - & $\begin{array}{c}\text { the coin at } \\
1.0 \mathrm{~m} \text { deep } \\
\text { was observed }\end{array}$ & - \\
\hline $\begin{array}{l}\text { 12:00 } \\
\text { p.m. }\end{array}$ & 8 & 1.5 & - & - & - & - & $\begin{array}{c}\text { the coin at } \\
1.0 \mathrm{~m} \text { deep } \\
\text { was observed }\end{array}$ & $\begin{array}{l}\text { service } \\
\text { finished }\end{array}$ \\
\hline $\begin{array}{l}\text { 2:00 } \\
\text { p.m. }\end{array}$ & 7.5 & 1 & - & - & - & - & $\begin{array}{c}\text { the coin at } \\
1.0 \mathrm{~m} \text { deep } \\
\text { was observed }\end{array}$ & $\begin{array}{c}\text { service } \\
\text { opening } \\
\text { with } 150 \\
\text { bathers } \\
\end{array}$ \\
\hline $\begin{array}{l}\text { 3:00 } \\
\text { p.m. }\end{array}$ & 7.5 & - & - & - & - & - & $\begin{array}{l}\text { the visibility } \\
\text { of the coin } \\
\text { at } 1.0 \mathrm{~m} \\
\text { decreased }\end{array}$ & - \\
\hline $\begin{array}{l}\text { 4:00 } \\
\text { p.m. }\end{array}$ & 8 & - & - & - & - & - & $\begin{array}{l}\text { the visibility } \\
\text { of the coin } \\
\text { at } 1.0 \mathrm{~m} \\
\text { decreased }\end{array}$ & - \\
\hline $\begin{array}{l}\text { 5:00 } \\
\text { p.m. }\end{array}$ & 7.95 & 0.25 & 15.5 & 0.425 & 22.15 & 3.5 & $\begin{array}{l}\text { the visibility } \\
\text { of the coin } \\
\text { at } 1.0 \mathrm{~m} \\
\text { decreased }\end{array}$ & $\begin{array}{l}\text { service } \\
\text { finished }\end{array}$ \\
\hline
\end{tabular}

Source: own study.

tous algae communities in three NSPs of Portugal. That latter $\mathrm{pH}$ figure represents a high alkaline media that promotes the growth of algae in aquatic systems.

The turbidity of the water of a swimming pool is attributed to the presence of dust, leaves and solid particles in suspension, or deposited in the bottom of the pooltub, that come from natural and anthropic actions. Other aspects such as wind, surrounding vegetation, addition of chemical compounds, rainfall, growth of microalgae and phytoplankton, and the bathers' own action, may also influence on the water turbidity. Cuban standards NC-22 [1999] and NC-441 [2006] establish that a swimming pool has adequate turbidity conditions if during its service the lowest pooltub sump, or a black circle of one centimetre in diameter, can be clearly observed from a depth of one meter. In the morning session the turbidity of the water satisfied the requisites of both standards, but at the end of the late session a decrease in the visibility of the pooltub sump was observed. This scenario was attributed to the incorporation of total and suspended solids by the anthropic action of the bathers, which, at this last stage, could not be completely removed by the phytodepuration system due to overload and lack of maturation of the wetland.

In the NSP swimming pool, the water used had an average concentration of free residual chlorine of $1.5 \mathrm{mg} \cdot \mathrm{dm}^{-3}$, the right value of drinkable water, but lower than the concentration recommended for the disinfection of artificial pools. At the end of the afternoon session, the concentration of chlorine decreased to $0.25 \mathrm{mg} \cdot \mathrm{dm}^{-3}$. This value was below the lower limit of the range established as permissible, $0.4-1.5 \mathrm{mg} \cdot \mathrm{dm}^{-3}$. The decrease and degradation of free residual chlorine was produced by the increase in water temperature and the action of sunlight. These two circum- 
stances were propitiated by the presence of a clear sky and an ambient temperature higher than $32^{\circ} \mathrm{C}$.

At the end of the afternoon session the nitrate and ammonium average concentrations were $15.5 \mathrm{mg} \mathrm{dm}^{-3}$ and $0.45 \mathrm{mg} \cdot \mathrm{dm}^{-3}$, respectively. The nitrate concentrations were within the allowed limits, but ammonium concentrations were slight above the allowed limits. The standard establishes that the nitrate and ammonium concentrations must not exceed the limit values of $20 \mathrm{mg} \cdot \mathrm{dm}^{-3}$ and 0.3 $\mathrm{mg} \cdot \mathrm{dm}^{-3}$, respectively. The elimination of nutrients in NSPs occurs in the filtration zone (artificial wetland), and in this experiment the latter had not reached optimum maturation. However, it was considered that the filtration zone could take on the nitrate and ammonium loads inherent to the use of the pool during a whole day. The values of nitrate and ammonium observed in our full-scale NSP were higher than those reported by GERALDES et al. [2014], 1.12 $\mathrm{mg} \cdot \mathrm{dm}^{-3}$ and $0.04 \mathrm{mg} \cdot \mathrm{dm}^{-3}$, respectively. These authors pointed out that the density of filamentous algae and phytoplankton decreased once the ecological balance was reached in the pools with well-established vegetation, as well as with the appearance of herbivore zooplankton.

Total and faecal coliforms concentrations determined at the end of the bath day evaluated remained below 200 NPM per $0.1 \mathrm{dm}^{3}$, which is the limit established in the standard. These results indicate that, despite the systematic contributions of organic pollutants, the NSP maintained an acceptable level of safety. Likewise, the present study suggests that the phytodepuration carried out by an AW for the treatment of swimming pool waters achieved a satisfactory level of efficiency in the removal of physical, chemical and microbiological contaminants, allowing the parameters of water quality to maintain the appropriate values for a safe bath. This research has shown that NSPs are an adequate and sustainable alternative to diversify recreational options, promoting the elimination of the use of chemical compounds for water disinfection, as well as the increase in economic benefits and the improvement of social and environmental impacts.

An appropriate uniform distribution of the water to treat on the WAs, and fundamentally the AW-SSF, is important, which can be accomplished with distribution pipes and removable lids that can simplify the cleanliness works. Besides, operation of the system is transcendental that be accomplished at intervals, i.e., when the bath service in the NSPs is offered, or the previous tasks to service. An efficient artificial wetland system make possible rest periods in some zones of the filter medium, avoiding the clogging of the filtration zone due to the natural process of biological degradation and biofilms growth. Once that the filter medium of the AW is clogging, cannot be recovered without rest periods; several researches have showed that uniform rest periods recover the permeability of the wetland almost completely [VYMAZAL 2014].

\section{CONCLUSIONS}

1. The findings of our work revealed that the removal of organic pollutants in the AWs of the NSPs was conditioned by the hydraulic load applied to the system and by the presence or absence of vegetation. In the laboratory scale bioreactors, the presence of vegetation favoured the reduction of nitrogen compounds and organic materials. In addition, the purification capacity of both laboratory scale bioreactors allowed pollutant concentration values to be lower than the maximum values established in the standards that regulate the quality of bathing water in swimming pools.

2. Typha domingensis is an appropriate plant to use in the WAs that compose the phytodepuration system on the NSPs. A coverage density of 4 plants per square meter of the wetland surface is advisable, with annual periods of harvesting and systematic pruning to avoid the clogging of the filter medium.

3. In the phytodepuration area of the AW-VSSF, efficiencies of elimination of faecal and total coliforms were greater than $90 \%$, and in the case of BOD the elimination efficiency reached $25.7 \%$, but whenever the hydraulic load applied was less than $0.25 \mathrm{~m}^{3} \cdot \mathrm{m}^{-2} \cdot \mathrm{h}^{-1}$.

\section{ACKNOWLEDGEMENTS}

The authors would like to thank the National Institute of Hydraulic Resources (INRH) and Hygiene and Epidemiology Laboratories of the Ministry of Public Health (MINSAP), Cuba, for granting funds for this research.

\section{REFERENCES}

APHA 1995. Standard methods for examination of water and wastewater. 19th ed. Washington D.C., USA. American Public Health Association pp. 1193.

ARIAS C.A., Del BubBA M., BRIX H. 2001. Phosphorus removal by sands for use as media in subsurface flow constructed reed beds. Water Research. Vol. 35 p. 1159-1168. DOI 10.1016/ S0043-1354(00)00368-7.

Arroyo P., SÁenz De Miera L., Ansola G. 2015. Influence of environmental variables on the structure and composition of soil bacterial communities in natural and constructed wetlands. Science of the Total Environment. Vol. 506-507 p. 380-390. DOI 10.1016/j.scitotenv.2014.11.039.

AUSTIN D. 2006. Influence of cation exchange capacity (CEC) in a tidal flow, flood and drain wastewater treatment wetland. Ecological Engineering. Vol. 28 p. 35-43.

BADHE N., SAHA S., BisWAS R., NANDY T. 2014. Role of algal biofilm in improving the performance of free surface, up-flow constructed wetland. Bioresource Technology. Vol. 169 p. 596-604. DOI 10.1016/j.biortech.2014.07.050.

Berninger K., Koskiaho J., TATTARI S. 2012. Constructed wetlands in Finnish agricultural environments: balancing between effective water protection, multi-functionality and socio-economy. Journal of Water and Land Development. Vol. 17 p. 19-29. DOI 10.2478/v10025-012-0029-5.

Boers A.M., Veltman R.L.D., ZedLer J.B. 2007. Typha×glauca dominance and extended hydroperiod constrain restoration of wetland diversity. Ecological Engineering. Vol. 29 p. 232244. DOI 10.1016/j.ecoleng.2006.04.011.

BriX H., ARIAS C.A. 2005. Danish guidelines for small-scale constructed wetland system for onsite treatment of domestic sewage. Water Science and Technology. Vol. 51 p. 1-9. DOI 10.2166/wst.2005.0275.

Casanovas-Massana A., Blanch A.R. 2013. Characterization of microbial populations associated with natural swimming pools. International Journal of Hygiene and Environmental Health. Vol. 216 p. 132-137. DOI 10.1016/j.ijheh.2012.04. 002 . 
CDC 2001. Shigellosis outbreak associated with an unchlorinated fill-and-drain wading pool - Iowa, 2001. Centres for Disease Control and Prevention. Morbidity and Mortality Weekly Report. Vol. 50. No. 37 p. 797-800.

CDC 2004. An outbreak of norovirus gastroenteritis at a swimming club - Vermont, 2004. Centres for Disease Control and Prevention. Morbidity and Mortality Weekly Report. Vol. 53. No. 34 p. 793-795.

Chanton J.P., Whiting G.J., Happell J.D., Gerard G. 1993. Contrasting rates and diurnal patterns of methane emission from emergent aquatic macrophytes. Aquatic Botany. Vol. 46 p. 111-128. DOI 10.1016/0304-3770(93)90040-4.

Chowdhury S., Alhooshani K., Karanfil T. 2014. Disinfection byproducts in swimming pool: Occurrences, implications and future needs. Water Research. Vol. 53 p. 68-109. DOI 10.1016/j.watres.2014.01.017.

Colford J., Wade T.J., Schiff K.C., Wright C.C., Griffith J.F., SANDHU S.K. 2007. Water quality indicators and the risk of illness at beaches with nonpoint sources of fecal contamination. Epidemiology. Vol. 18 p. 27-35. DOI 10.1097/01. ede.0000249425.32990.b9.

Coveney M.F., Stites D.L., Lowe E.F., Battoe L.E., Conrow R. 2002. Nutrient removal from eutrophic lake by wetland filtration. Ecological Engineering. Vol. 19 p. 141-159. DOI 10.1016/S0925-8574(02)00037-X.

Craun G.F., Berger P.S., Calderon R.L. 1997. Coliform bacteria and waterborne disease outbreaks. Journal of American Water Works Association. Vol. 99 p. 96-104. DOI 10.1002/ j.1551-8833.1997.tb08197.x.

Cui L., OuYAng Y., Lou Q., Yang F., Chen Y., Zhu W., LuO S. 2010. Removal of nutrients from wastewater with Canna indica L. under different vertical-flow constructed wetland conditions. Ecological Engineering. Vol. 36 p. 1083-1088. DOI 10.1016/j.ecoleng.2010.04.026.

DEBUSK W.F. 1999. Wastewater treatment wetlands: Applications and treatment efficiency. Soil and Water Science Department, Florida Cooperative Extension Service, Institute of Food and Agricultural Sciences. SL 156 pp. 6.

Dordio A.V., CARVAlHo A.J.P. 2013. Organic xenobiotics removal in constructed wetlands, with emphasis on the importance of the support matrix. Journal of Harzadous Materials. Vol. 252-253 p. 272-292. DOI 10.1016/j.jhazmat.2013. 03.008 .

Eid E.M., Shaltout K.H., Asaeda T. 2012. Modeling growth dynamics of Typha domingensis (Pers.) Poir. ex Steud. in Lake Burullus, Egypt. Ecological Engineering. Vol. 243 p. 63-72. DOI 10.1016/j.ecolmodel.2012.05.028.

Faulwetter J.L., Gagnon V., Sundberg C., Chazarenc F., BurR M.D., Brisson J., CAMPER A.K., SteIN O.R. 2009. Microbial processes influencing performance of treatment wetlands: A review. Ecological Engineering. Vol. 35 p. $987-$ 1004. DOI 10.1016/j.ecoleng.2008.12.030.

Fiorillo L., Zucker M., SAWYer D., Lin A.N. 2001. The Pseudomonas hot-foot syndrome. The New England Journal of Medicine. Vol. 345 p. 335-338. DOI 10.1056/NEJM 200108023450504.

Florentin A., Hautemanière A., Hartemann P. 2011. Health effects of disinfection by-products in chlorinated swimming pools. International Journal of Hygiene and Environmental Health. Vol. 214 p. 461-469. DOI 10.1016/j.ijheh.2011.07. 012 .

Geraldes A.M., BoAvidA M.J. 2004. How important are emergent macrophytes to crustacean zooplankton in a mesoeutrophic reservoir? Limnetica. Vol. 23 p. 57-64. DOI 10.1590/S2179-975X2013005000010.

Geraldes A.M., Schwarzer C., Schwarzer U. 2014. Piscinas biológicas e serviços ecossistémicos: Que relação? [Biologi- cal pools and ecosystem services: What relationship?] [online]. Ciência e ambiente para todos. Vol. 5 p. 27-36. [Access 14.04.2018]. Available at: http://revistas.ua.pt/index. php/captar/article/download/2968/2763.

Gomes M.V.T., Souza R.R.D., Teles V.S., Mendes É.A. 2013. Phytoremediation of water contaminated with mercury using Typha domingensis in constructed wetland. Chemosphere. Vol. 103 p. 228-233. DOI 10.1016/j.chemosphere.2013.11. 071.

GonZÁLEZ O. 2000. Estudio del comportamiento de humedales con flujo subsuperficial horizontal en el tratamiento de aguas residuales [Study of the behaviour of wetlands with horizontal subsurface flow for wastewater treatment]. PhD Thesis. La Habana. CUJAE pp. 120.

GONZÁlEZ O. 2006. Remoción de nitrógeno y fósforo en humedales con flujo subsuperficial horizontal [Nitrogen and phosphorus removal in wetlands with horizontal subsurface flow]. Ingeniería Hidráulica y Ambiental. Vol. 17 p. 26-31. DOI 10.4067/S0718-07642015000600011.

Gross M.F., Hardisky M.A., Wolf P.L., Klemas V. 1993. Relationships among Typha biomass, pore water methane, and reflectance in a Delaware (USA) brackish marsh. Journal of Coastal Research. Vol. 9 p. 339-355.

Guittonny-Philippe A., Masotti V., HöHener P., Boudenne J.-L., Viglione J., LAfFont-SchwoB I. 2014. Constructed wetlands to reduce metal pollution from industrial catchments in aquatic Mediterranean ecosystems: A review to overcome obstacles and suggest potential solutions. Environment International. Vol. 64 p. 1-16. DOI 10.1016/j.envint.2013. 11.016.

HaRrington C, SchOlz M. 2010. Assessment of pre-digested piggery wastewater treatment operations with surface flow integrated constructed wetland systems. Bioresource Technology. Vol. 101 p. 7713-7723. DOI 10.1016/j.biortech. 2010. 03.147.

Hegazy A.K., Abdel-Ghani N.T., El-Chaghaby G.A. 2011. Phytoremediation of industrial wastewater potentiality by Typha domingensis. International Journal of Environmental Science and Technology. Vol. 8 p. 639-648.

Hildebrand J.M., Maguire H.C., Holliman R.E., Kangesu E. 1996. An outbreak of Escherichia coli O157:H7 infection linked to paddling pools. Communicable disease report. CDR review. Vol. 6 p. 33-36.

JÓŹWIAKOWSKI K. 2017. Efficiency of organic substance removal in a hybrid sand filter with horizontal flow. Journal of Water and Land Development. Vol. 35 p. 95-100. DOI 10.1515/ jwld-2017-0072.

Knowles P., Dotrob G., Nivala J., Garcia J. 2011. Clogging in subsurface-flow treatment wetlands: occurrence and contributing factors. Ecological Engineering. Vol. 37 p. 99-112. DOI 10.1016/j.ecoleng.2010.08.005.

Koukia S., M'Hirib F., Saidia N., Belaïdb S., Hassena A. 2009. Performances of a constructed wetland treating domestic wastewaters during a macrophytes life cycle. Desalination. Vol. 246 p. 452-467. DOI 10.1016/j.desal.2008.03. 067.

Kramer M.H., Herwaldt B.L., Craun G.F., Calderon R.L, JURANEK D.D. 1996. Surveillance for waterborne-disease outbreaks - United States, 1993-1994. Morbidity and Mortality Weekly Report. Vol. 45. No. 1 p. 1-33.

Levy D.A., Bens M.S., Craun G.F., Calderon R.L., HerWALDT B.L. 1998. Surveillance for waterborne-disease outbreaks - United States, 1995-1996. Morbidity and Mortality Weekly Report. Vol. 47. No. SS-5 p. 1-34.

Li J., Wen Y., Zhou Q., XingJie Z., Li X., Yang S., Lin T. 2008. Influence of vegetation and substrate on the removal and transformation of dissolved organic matter in horizontal sub- 
surface-flow constructed wetlands. Bioresource Technology. Vol. 99 p. 4990-4996. DOI 10.1016/j.biortech.2007.09. 012.

Marion J.W., LeE J., Lemeshow S., BuCKLEY T.J. 2010. Association of gastrointestinal illness and recreational water exposure at an inland U.S. beach. Water Research. Vol. 44 p. 4796-4804. DOI 10.1016/j.watres.2010.07.065.

MCCRADY M.H. 1915. The numerical interpretation of fermentation-tube. The Journal of Infectious Diseases. Vol. 17. No. 1 p. 183-212.

MiodusZEWSKI W. 2014. Small (natural) water retention in rural areas. Journal of Water and Land Development. Vol. 20 p. 19-29. DOI 10.2478/jwld-2014-0005.

NC-22 1999. Lugares de baño en costas y en masas de aguas interiores. Requisitos higiénico sanitarios [Places of bath at coasts and on masses of interior waters. Hygienic sanitary requirements]. La Habana. Oficina Nacional de Normalización pp. 10.

NC-441. 2006. Salud ambiental Piscinas requisitos higiénico sanitarios y de seguridad [Environmental health - Swimming pools - Safety and sanitary hygienic requirements]. La Habana. Oficina Nacional de Normalización pp. 22.

Newman S., Grace J.B., Koebel J.W. 1996. Effects of nutrient and hydroperiod on Typha, Cladium and Eleocharis: Implications for everglades restoration. Ecological Applications. Vol. 6 p. 774-783. DOI 10.2307/2269482.

POND K. 2005. Water recreation and disease. Plausibility of associated infections: Acute effects, sequelae and mortality. London. WHO. ISBN 1843390663 pp. 239.

RICHARDSON S.D. 2010. Environmental mass Spectrometry: emerging contaminants and current issues. Analytical Chemical. Vol. 82 p. 4742-4774. DOI 10.1021/ac202903d.

Richardson S.D., DeMarini D.M., Kogevinas M., FernandeZ P., Marco E., Lourencetti C., Ballesté C., Heederik D., Meliefste K., McKague AB. 2010. What's in the pool? A comprehensive identification of disinfection by-products and assessment of mutagenicity of chlorinated and brominated swimming poolwater. Environmental health perspectives. Vol. 118 p. 1523-1530. DOI 10.1289/ehp.1001965.

SAEED T., Sun G. 2012. A review on nitrogen and organics removal mechanisms in subsurface flow constructed wetlands: dependency on environmental parameters, operating conditions and supporting media. Journal of Environmental Management. Vol. 112 p. 429-448. DOI 10.1016/j.jenvman. 2012.08.011.

SAEED T., Sun G. 2013. A lab-scale study of constructed wetlands with sugarcane bagasse and sand media for the treatment of textile wastewater. Bioresource Technology. Vol. 128 p. 438-447. DOI 10.1016/j.biortech.2012.10.052.

Schroder P., Neustifter J., Peis S., Huber B. 2003. Perspectives for the use of cattail (Typha spp.) in phytoremediation. In: Crop Science and Technology. Proceedings of the International Congress (BCPC). Glasgow. British Crop Production Council p. 405-412.

Sharma P., Asaeda T., Manatunge J., Fujino T. 2006. Nutrient cycling in a natural stand of Typha angustifolia. Journal of Freshwater Ecology. Vol. 21 p. 431-438. DOI 10.1080/ 02705060.2006.9665020

SinClair R.G., Jones E.L., Gerba C.P. 2009. Viruses in recreational water-borne disease outbreaks: a review. Journal of Applied Microbiology. Vol. 107 p. 1769-1780. DOI 10.1111/j.1365-2672.2009.04367.x.

SKRZYPIEC K., GAJEWSKA M. 2017. The use of constructed wetlands for the treatment of industrial wastewater. Journal of Water and Land Development. Vol. 34 p. 233-240. DOI 10.1515/jwld-2017-0058.
Sultana M.-Y., Akratos C.S., Pavlou S., Vayenas D.V. 2014. Chromium removal in constructed wetlands: A review. International Biodeterioration and Biodegradation. Vol. 96 p. 181-190. DOI 10.1016/j.ibiod.2014.08.009.

Teo T.L.L., Coleman H.M., Khan S.J. 2015. Chemical contaminants in swimming pools: Occurrence, implications and control. Environment International. Vol. 76 p. 16-31. DOI 10.1016/j.envint.2014.11.012.

Tirodimos I., Arvanitidou M., Dardavessis L., BisiKlis A., Alexiou-Danill S. 2010. Prevalence and antibiotic resistance of Pseudomonas aeruginosa isolated from swimming pools in northern Greece. Eastern Mediterranean Health Journal. Vol. 16 p. $783-787$.

USEPA 2000. Design manual constructed wetlands for municipal wastewater treatment. U.S. Environmental Protection Agency (USEPA), Cincinnati, Ohio, USA pp. 166.

VYMAZAL J. 2007. Removal of nutrients in various types of constructed wetlands. Science of the Total Environment. Vol. 380 p. 48-65. DOI 10.1016/j.scitotenv.2006.09.014.

VYMAZAL J. 2011. Constructed wetlands for wastewater treatment: five decades of experience. Environmental Science and Technology. Vol. 45 p. 61-69. DOI 10.1021/es101403q.

VYMAZAL J. 2013. Emergent plants used in free water surface constructed wetlands: A review. Ecological Engineering. Vol. 61 p. 582-592. DOI 10.1016/j.ecoleng.2013.06.023.

VymaZAL J. 2014. Constructed wetlands for treatment of industrial wastewaters: A review. Ecological Engineering. Vol. 73 p. 724-751. DOI 10.1016/j.ecoleng.2014.09.034.

Wade T.J., CALDERON R.L., SAMS E., Beach M., Brenner K.P., Williams A.H., DufouR A.P. 2006. Rapidly measured indicators of recreational water quality are predictive of swimming-associated gastrointestinal illness. Environmental Healt Perspectives. Vol. 114 p. 24-28. DOI 10.1289/ehp. 8273.

WHO 2006. Microbial hazards. Chapt. 3. In: Guidelines for safe recreational water environments. swimming pools and similar environment. Vol. 2. Geneva. WHO Press p. 26-59.

Wu H., Zhang J., NGo H.H., Guo W., Hu Z., Liang S., Fan J., LIU H. 2015. A review on the sustainability of constructed wetlands for wastewater treatment: Design and operation. Bioresource Technology. Vol. 175 p. 594-601. DOI 10.1016/ j.biortech.2014.10.068.

Wu S., Kuschk P., Brix H., Vymazal J., Dong R. 2014. Development of constructed wetlands in performance intensifications for wastewater treatment: A nitrogen and organic matter targeted review. Water Research. Vol. 57C p. 40-55. DOI 10.1016/j.watres.2014.03.020.

Yalcuk A., Ugurlu A. 2009. Comparison of horizontal and vertical constructed wetland systems for landfill leachate treatment. Bioresource Technology. Vol. 100 p. 2521-2526. DOI 10.1016/j.biortech.2008.11.029.

Yang L., Schmalz C., Zhou J., Zwiener C., Chang V.W.-C., Ge L., Wan M.P. 2016. An insight of disinfection by-product (DBP) formation by alternative disinfectants for swimming pool disinfection under tropical conditions. Water Research. Vol. 101 p. 535-546. DOI 10.1016/j.watres.2016.05.088.

Yoder J.S., Blackburn B.G., Craun G.F., Hill V., LeVy D.A., Chen N., Lee S.H., Calderon R.L., Beach M.J. 2004. Surveillance for waterborne-disease outbreaks associated with recreational water - United States, 2001-2002. Morbidity and mortality weekly report. Surveillance summaries. Vol. 53. No. 8 p. $1-22$.

Zwiener C., Richardson S.D., De Marini D.M., Grummt T., GlaUNER T., Frimmel F.H. 2007. Drowning in disinfection byproducts? Assessing swimming pool water. Environmental Science and Technology. Vol. 41 p. 363-372. DOI 10.1021/ es062367v. 
Yans GUARDIA-PUEBLA, Fernando PÉREZ-QUINTERO, Suyén RODRÍGUEZ-PÉREZ, Víctor SÁNCHEZ-GIRÓN, Edilberto LLANES-CEDEÑO, Juan ROCHA-HOYOS, Diana PERALTA-ZURITA

\author{
Wpływ obciążenia hydraulicznego i roślinności na fitoremediację w sztucznych mokradłach powiązanych \\ z naturalnymi basenami pływackimi
}

\title{
STRESZCZENIE
}

Fitoremediacja jest szeroko stosowana do oczyszczania wody w rekreacyjnych i sportowych basenach pływackich. W pracy oceniono dwa sztuczne mokradła: jeden w rzeczywistej skali i drugi w skali laboratoryjnej, które obsadzono $T y$ pha domingensis w celu oczyszczania wody w basenie w klimatycznych warunkach Santiago de Cuba. Kiedy obciążenie hydrauliczne układu w skali rzeczywistej było mniejsze od $0,25 \mathrm{~m}^{3} \cdot \mathrm{m}^{-2} \cdot \mathrm{d}^{-1}$, stężenie zanieczyszczeń organicznych i mikrobiologicznych było mniejsze niż maksymalne limity wyznaczone przez kubańskie normy. W skali laboratoryjnej obecność roślinności sprzyjała eliminowaniu związków azotowych (azotanów i jonów amonowych) oraz materii organicznej (BZT i ChZT). Taki efekt tłumaczy się występowaniem procesów asymilacji związków organicznych lub aktywnością mikroorganizmów powiązanych z kłączami roślin, które tworzą symbiotyczny system korzystny dla oczyszczania. Minimalne stężenie jonów amonowych mierzone na odpływie z laboratoryjnego reaktora bez roślinności wynosiło $2,15 \mathrm{mg} \cdot \mathrm{dm}^{-3}$; mieściło się więc w granicach dopuszczalnych przez normy sanitarne.

Słowa kluczowe: fitoremediacja, naturalne baseny pływackie, sztuczne mokradła, Typha domingensis 